\title{
ALTERNATIF PRODUK PANGAN ANAK JENIS SEMPOL BERZAT BESI SEBAGAI TAMBAHAN SUMBER ZAT BESI ANAK
}

\author{
Amallia Puspitasari ${ }^{1}$, Broto Widya Hartanto \\ ${ }^{1}$ Teknik Industri, Fakultas Teknik Industri, Institut Teknologi Yogyakarta
}

\section{INTISARI}

Dalam penelitian ini dilakukan dalam skala laboratorium yang memiliki tujuan untuk membuat produk pangan anak jenis sempol dengan tambahan daun kelor yang dapat dijadikan sebagai alternatif sumber zat besi untuk anak dan menganalisis kandungan zat besinya.

Metode yang digunakan dalam penelitian ini adalah metode deskriftif dan dalam pengujian kandungan zat besi menggunakan metode spektofotometri visibel dengan parameter zat besi.

Hasil penelitian didapatkan produk sempol dengan campuran daun kelor sebanyak 3 macam, yaitu 35 gram, 50 gram dan 70 gram. Kandungan zat besi dari masing-masing variasi adalah $8,307 \mathrm{mg} / 100 \mathrm{~g} ; 15,2786 \mathrm{mg} / 100 \mathrm{~g} ; 19,4376 \mathrm{mg} / 100 \mathrm{~g}$. Dari hasil diharapkan dapat menjadi sumber alternatif pangan sumber zat besi bagi anak. Selain itu, diharapkan dapat dilakukan pengujian lebih lanjut untuk minat konsumsi terhadap produk ini.

Kata Kunci : Sempol, kelor, zat besi.

\begin{abstract}
In this study carried out on a laboratory scale which has the purpose of making perfect food products "sempol" for children with additional Moringa leaves which can be used as an alternative source of iron for children and analyze the iron content.

The method used in this study is descriptive method and in testing the iron content using a visible spectrophotometric method with Ferum parameters.

The results of the study showed that there were 3 kinds of splinter products with a mixture of Moringa leaves, namely 35 grams, 50 grams and 70 grams. The iron content of each variation is $8,307 \mathrm{mg} / 100 \mathrm{~g} ; 15,2786 \mathrm{mg} / 100 \mathrm{~g} ; 19,4376 \mathrm{mg} /$ $100 \mathrm{~g}$.

The results are expected to be an alternative source of food for iron for children. In addition, it is hoped that further testing can be made of interest in consumption of this product.
\end{abstract}

Keyword: Sempol, Moringa, Ferum. 


\section{PENDAHULUAN}

Di Indonesia, permasalahan gizi tidak akan lepas dari permasalahan pangan. Hal ini karena tubuh memerlukan sejumlah pangan dan gizi secara tetap sesuai dengan standar angka kecukupan gizi (AKG). Akan tetapi kebutuhan akan asupan gizi tersebut tidak selalu terpenuhi. Mayoritas penduduk kurang mampu belum dapat mencukupi kebutuhan pangan yang bergizi sesuai standarnya. Atau bahkan, penduduk yang tergolong dalam kalangan atas bisa juga mendapatkan asupan gizi yang tidak sesuai standarnya karena beberapa alasan, misalnya tidak suka dengan makanan tertentu. Sehingga mengakibatkan banyaknya yang kekurangan asupan gizi baik dari golongan bawah ataupun golongan atas. Hingga saatini di indonesia masihterdapat4masalahgiziutamayaitu

KKP (KurangKalori Protein), kurangvitaminA, GangguanAkibatKura ng Iodium(GAKI) dan kurangzat besi yang disebut Anemia Gizi (Kodyat, 1992).

\section{Berdasarkan data dari Ikatan \\ Dokter Anak Indonesia, angka kekurangan gizi zat besi (anemia) pada balita mencapai 40-45 \%. Pada anak balita, keadaan kekurangan zat besi secara perlahan-lahan akan menghambat pertumbuhan dan perkambangan kecerdasan, anak- anak akan lebih mudah terserang}

penyakit karena penurunan daya tahan tubuh, dan hal ini tentu akan melemahkan keadaan anak sebagai generasi penerus (Wijayanti, 1989 dalam Wahyuni, 2004). Penyebab utama kekurangan zat besi adalah konsumsi zat besi yang tidak cukup dan absorbsi zat besi yang rendah serta pola makan yang sebagian besar terdiri dari nasi dan menu yang kurang beraneka ragam.

Sumber utama zat besi adalah sayur-sayuran, buah-buahan, dan daging. Ketiga jenis tersebut kurang disukai oleh anak balita, sehingga perlu adanya suatu jenis makanan yang menarik bagi balita dan mempunyai asupan zat besi yang cukup.

Makanan yang disukai oleh anak biasanya merupakan makanan siap saji dengan berbagai macam jenis. Salah satu cara untuk mengatasi permasalahan dapat membuat variasi olahan semacam jajanan di pinggir jalan. Seperti yang sekarang ini sedang diminati banyak anak balita, yaitu sempol.

Sempol dapat divariasikan dengan mencampur berbagai macam sayuran yang kaya akan zat besi. Salah satu sayuran yang mudah dan murah didapatkan tetapi kaya akan zat besi adalah daun kelor. Daun kelor mengandung zat besi lebih tinggi daripada sayuran lainnya yaitu sebesar $17,2 \mathrm{mg} / 100$ gram (Yameogi et al., 2011). Sehingga daun kelor dapat 
dimanfaatkan sebagai campuran bahan pembuatan sempol yang dapat meningkatkan asupan zat besi pada anak.

Dari latar belakang tersebut dapat diketahui kebutuhan sumber makanan untuk menambah asupan zat besi bagi pertumbuhan anak. Sehingga penting dilakukan pengembangan sebuah produk makanan baru yang berzat besi yang dibutuhkan oleh pertumbuhan anak.

Sumber makanan yang mengandung zat besi dapat berasal baik dari hewani (daging, ayam, ikan, dan telur) maupun nabati (kacangkacangan, sayuran hijau, dan pisang ambon). Keanekaragaman konsumsi makanan berperan penting dalam membantu meningkatkan penyerapan Fe di dalam tubuh. Kehadiran protein hewani, vitamin $\mathrm{C}$, vitamin A, asam folat, zat gizi mikro lain dapat meningkatkan penyerapan zat besi dalam tubuh. Manfaat lain dari mengkonsumsi makanan sumber zat besi adalah terpenuhinya kecukupan vitamin A, karena makanan sumber zat besi biasanya juga merupakan sumber vitamin A (Almatsier, 2002).

Kandungan nilai gizi yang tinggi pada daun kelor, khasiat dan manfaatnya menyebabkan kelor mendapat julukan sebagai Mother's Best Friend and Miracle Tree. Namun di Indonesia sendiri pemanfaatan kelor masih belum banyak diketahui, umumnya hanya dikenal sebagai salah satu menu sayuran. Selain dikonsumsi langsung dalam bentuk segar, kelor juga dapat diolah menjadi bentuk tepung atau powder yang dapat digunakan sebagai bahan fortifikan untuk mencukupi nutrisi pada berbagai produk pangan, seperti pada olahan puding, cake, nugget, biskuit, cracker, serta olahan lainnya. Menurut Prajapati, et.al. (2003) tepung daun kelor dapat ditambahkan untuk setiap jenis makanan sebagai suplemen gizi.

Daun kelor merupakan salah satu bagian dari tanaman kelor yang telah banyak diteliti kandungan gizi dan kegunaannya. Daun kelor sangat kaya akan nutrisi, diantaranya kalsium, zat besi, protein, vitamin $\mathrm{A}$, vitamin $\mathrm{B}$, dan vitamin C (Misra dan Misra, 2014).

Sempol adalah kuliner perpaduan antara daging ayam yang digiling halus bersama tepung terigu dan kanji, lalu dikepal mirip mendol, ditusuk menggunakan tusukan dari bambu sepanjang $30 \mathrm{~cm}$ dan dicelupkan ke larutan telur sebelum digoreng. Nama sempol sendiri merupakan nama sebuah desa di wilayah Kecamatan Pagak, Kabupaten Malang. Mayoritas penduduk desa ini bermatapencaharian sebagai petani musiman (Akaibara, 2017). 


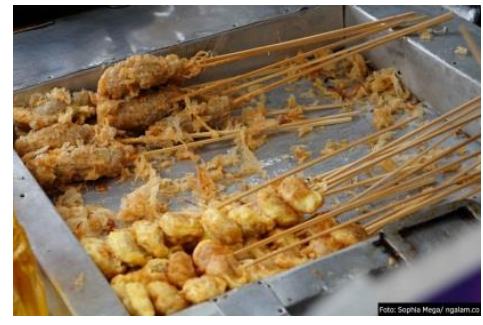

Gambar 1. Jajanan sempol (Mega, 2016)

\section{Metodologi Penelitian}

Penelitian ini dilakukan untuk membuat produk makanan yang mengandung zat besi. Eksperimen ini dilakukan dalam skala laboratorium dengan metode deskripsi.

Adapun bahan-bahan yang digunakan dalam penelitian ini adalah daging ayam, terigu, tepung kanji, dan daun kelor, bawang putih, Asamnitrat (HNO3) pekat, Asamnitrat (HNO3), Asamsulfat $\left(\mathrm{H}_{2} \mathrm{SO}_{2}\right)$ pekat, Kalium persulfat $\quad\left(\mathrm{K}_{2} \mathrm{~S}_{2} \mathrm{O} 8\right), \quad$ Kristal besi(II)amoniumsulfat[FeSO4(NH4)2S $\left.\mathrm{O}_{46} \mathrm{H}_{2} \mathrm{O}\right]$ dan aquadest.

Alat yang dipakai dalam percobaan pengembangan produk pangan berzat besi ini adalah 1 set spektrofotometer, penggiling daging, spatula dan baskom.

Tahapan pertama dalam penelitian ini adalah produksi sempol. Proses produksinya sangat sederhana yaitu, sebanyak 400 gram daging ayam dan 5 siung bawang putih digiling dengan menggunakan blender. Adonan yang sudah digiling dicampur dengan 4 sendok makan tepung terigu, 2 sendok makan tepung kanji, 1 butir telur, lada bubuk, garam dan sedikit gula pasir kemudian diuleni hingga kalis. Setelah adonan kalis tambahkan daun kelor yang sudah dicincang halus dan uleni kembali hingga kalis.

Bentuk adonan dengan dililitkan pada tusuk es krim kemudian masak dalam air mendidih selama 15 menit dan tiriskan. Dari adonan kemudian ditambahkan daun kelor sebanyak 35 gram, 50 gram dan 75 gram sebagai sumber zat besinya.

Tahapan kedua dari penelitian ini adalah dengan menguji secara fisik. Pengujian fisik pada sempol dilakukan secara visual dengan pengamatan langsung terhadap warna, rasa dan baunya.

Tahapan terakhir dari penelitian ini adalah pengujian zat besi dari produk sempol. Analisa zat besi dilakukan dilakukan dengan menggunakan metodeSpektrofotometri Visibel.

\section{PEMBAHASAN}

Produk sempol yang dapat diproduksi dalam penelitian ini dapat ditunjukan dengan Gambar 2. 


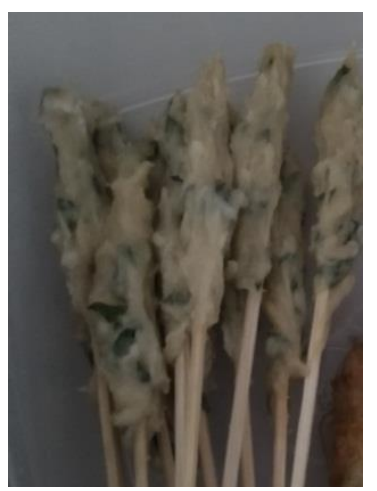

Gambar 1. Produk Sempol

Berdasarkan penelitian ini didapatkan hasil berupa produk sempol yang sudah divariasi dengan sumber zat besi yaitu daun kelor. Produk yang dikembangan ada 3 variasi massa sumber zat besi.

Hasil droduk dengan 3 variasi ini kemudian diuji secara organoleptik. Adapun hasil ujinya adalah sebagai berikut

Tabel1. Uji Organoleptik Sempol

\begin{tabular}{|c|c|c|c|}
\hline \multicolumn{4}{|c|}{ UJI ORGANOLEPTIK } \\
\hline $\begin{array}{c}\text { MASSA } \\
\text { (gram) }\end{array}$ & $\begin{array}{c}\text { WAR } \\
\text { NA }\end{array}$ & $\begin{array}{c}\text { RAS } \\
\text { A }\end{array}$ & BAU \\
\hline 35 gr & $\begin{array}{c}\text { hijau } \\
\text { muda }\end{array}$ & $\begin{array}{c}\text { tidak } \\
\text { terasa }\end{array}$ & $\begin{array}{c}\text { kurang } \\
\text { berbau }\end{array}$ \\
\hline 50 gr & Hijau & terasa & $\begin{array}{c}\text { agak } \\
\text { berbau }\end{array}$ \\
\hline & hijau & $\begin{array}{c}\text { sanga } \\
\text { tua } \\
\text { terasa }\end{array}$ & $\begin{array}{c}\text { sangat } \\
\text { berbau }\end{array}$ \\
\hline
\end{tabular}

Hasil Penelitian 2018

Berdasarkan pada Tabel 1. Uji Organoleptik di atas, dapat disimpulkan bahwa sempol yang ditambahkan kelor dengan massa 35 gram akan menghasilkan sempol dengan hasil warna hijau muda, rasa kelor yang tidak terasa, dan tidak berbau kelor. Sedangkan kelor dengan massa 50 gram akan menghasilkan sempol dengan hasil warna hijau, rasa kelor yang terasa, dan tidak terlalu bau kelor. Dan untuk kelor dengan massa 75 gram akan menghasilkan sempol dengan hasil warna hijau tua, rasa kelor yang sangat terasa, dan sangat berbau kelor.

Setelah Pengujian Organoleptik maka dilakukan pengujian kadar zat besi dengan metode spektofotometri visibel dengan hasil sebagai berikut. Pada penambahan kelor 35 gram kandungan zat besi dalam satu tusuk sempol adalah 8,307 mg/100g; pada penambahan daun kelor 50 gram terkandung $15,2786 \mathrm{mg} / 100 \mathrm{~g}$; dan untuk penambahan daun kelor 75 gram terukur kandungan zat besinya adalah $19,4376 \mathrm{mg} / 100 \mathrm{~g}$.

Berdasarkan data tersebut dapat dikatakan bahwa pengembangan produk sempol yang dihasilkan mempunyai kandungan zat besi sehingga apabila dikonsumsi akan menambah asupan zat besi untuk tubuh.

\section{KESIMPULAN}

Berdasarkan hasil penelitian dan pembahasan dapat diambil kesimpulan sebagai berikut : 
1. Diperoleh hasil produk pangan berjenis sempol dengan kandungan zat besi $8,307 \mathrm{mg} / 100 \mathrm{~g} ; 15,2786 \mathrm{mg} / 100 \mathrm{~g}$ ; 19,4376mg/100g.

2. Kandungan zat besi dalam sempol dapat dijadikan sumber anternatif tambahan zat besi.

\section{SARAN}

1. Agar dilakukan pengujian lanjutan terhadap minat konsumsi produk sempol dengan daun kelor.

2. Dibuat pengembangan produk yang lain dengan nilai gizi zat besi yang tinggi.

\section{DAFTAR PUSTAKA}

Akaibara, 2017. Mengenal Desa Sempol yang Katanya Asal Kuliner Sempol. <https://ngalam.co/2017/03/17/m engenal-desa-sempol-katanyaasal-kuliner-sempol/> (diakses tanggal 5 Juni 2017).

Almatsier, S., 2002. Prinsip Dasar Ilmu Gizi. Jakarta: Gramedia Pustaka Utama.

Kodyat, B.A., 1992. Masalah Gizi di Indonesia dan Penanggulangannya. Direktorat Bina Gizi Indonesia.

Misra, S., and Misra, M.K., 2014. Nutritional evaluation of some leafy vegetable used by the tribal and rural people of south Odisha, India. Journal of Natural Product and Plant Resources (4): 23-28.Prajapati, R.D., Murdia, P.C., Yadav, C.M., Chaudhary, J.L., 2003. Nutritive value of drumstick (Moringa oleifera) leaves in sheep and goats. Indian Journal of Small Ruminants (2): 136-137.

Wahyuni, A.S., 2004. Anemia Defisien Besi pada Balita. Medan. FK USU.

Yameogo, W.C., Bengaly, D.M., Savadogo, A., Nikiema, P.A., Traore, S.A., 2011.

Determination of chemical composition and nutritional values of Moringa oleifera leaves. Pakistan Journal of Nutrition 10 Vol (3): 264-268. 
